\title{
DESKRIPSI HASIL BELAJAR MATEMATIKA SISWA GAYA KOGNITIF FIELD INDEPENDENT DAN FIELD DEPENDENT
}

\author{
Wahyuni H.Mailili ${ }^{\bowtie}$ \\ Prodi Pendidikan Matematika, Universitas Alkhairaat Palu
}

\begin{tabular}{l}
\hline Info Artikel \\
\hline Sejarah Artikel: \\
Diterima 24 Feb 2018 \\
Direvisi 20 Mar 2018 \\
Disetujui 20 Apr 2018 \\
\hline \\
Keywords : Mathematic \\
learning outcomes, \\
cognitive style, field \\
independent, field \\
dependent
\end{tabular}

Paper type:

Research paper

\begin{abstract}
The purpose of this research is describing students' mathematics learning outcomes on phytagoras theorem with Field Dependent cognitive style (FD) and Cognitive Field Independent (Fl) style in Mts. Alkhairaat Kalukubula. This research is a descriptive with population 104 student of Mts. Alkhairaat kalukubula grade VIII in academic year of 2016/2017. The selection of data was conducted by using simple random sampling technique, the sample chosen were two cognitive style student of Field Dependent cognitive style and Cognitive Field Independent with 40 student from each cognitive style. Data obtained were analyzed using statistic description to describe the characteristics of research variables by using the Maximum and Minimum value, mean, standard deviation, variance and percentage frequency table. Learning outcomes with Field Dependent cognitive style (FD) in very low category obtained an average value of 49.40 from ideal score 100 , Standard deviation 16.17 and Variance 261.528. The results with cognitive style Field Independent (Fl) in the category being obtained with an average value of 75.10 from the ideal score of 100, Standard deviation 9.18 and variance 84.30. Based on these results it's concluded that the cognitive style of Field Independent is more contribute than the cognitive style of Field Dependent in solving the phytagoras theorem question.
\end{abstract}

\begin{abstract}
Abstrak
Penelitian ini bertujuan untuk Mendeskripsikan hasil belajar matematika siswa pada materi teorema phytagoras dengan gaya kognitif Field Dependent (FD) dan gaya kognitif Field Independent (Fl) di Mts.Alkhairaat Kalukubula. Jenis penelitian yang digunakan adalah penelitian deskriptif dengan populasi seluruh siswa kelas VIII Mts Alkhairaat Kalukubula yang terdaftar pada tahun ajaran 2016/2017 sebanyak 104 siswa. Teknik pengambilan data yaitu random sampling dipilih 40 siswa gaya kognitif Field Dependent (FD) dan 40 siswa Field Independent (Fl). ). Data yang diperoleh di analisis menggunakan analisis statistik deskriptif dimaksudkan untuk mendeskripsikan karakteristik variabel penelitian dengan menggunakan skor tertinggi, skor terendah, rata-rata, standar deviasi, variansi dan tabel frekuensi persentase. Hasil belajar dengan gaya kognitif Field Dependent (FD) berada pada kategori sangat rendah diperoleh nilai rata-rata 49,40 dari skor ideal 100. Standar deviasi 16,17 dan Variansi 261,528. Sedangkan hasil dengan gaya kognitif Field Independent (Fl), berada pada kategori sedang diperoleh dengan nilai rata-rata 75,10 dari skor ideal 100. Standar deviasi 9,18 dan variansi 84,30. Berdasarkan hasil tersebut dapat disimpulkan bahwa gaya kognitif Field Independent lebih tinggi dibandingkan dengan gaya kognitif Field Dependent dalam menyelesaiakan soal materi teorema phytagoras dengan kata lain gaya kognitif berkonstribusi pada hasil belajar matematika siswa.
\end{abstract}

(C) 2018 Universitas Muria Kudus 


\section{PENDAHULUAN}

Dewasa ini, masyarakat dituntut mampu memanfaatkan pengetahuannya secara optimal agar lebih cerdas dan kritis dalam menerima dan mengolah informasi. Hal ini sangat penting untuk menunjang pemecahan masalah yang semakin kompleks. Menjawab tuntutan sekaligus kebutuhan zaman inilah, pendidikan memegang peran penting dalam menyiapkan generasi bangsa yang berkompeten, termasuk di dalamnya adalah penguasan matematika dan pemahamannya secara holistik. Matematika menjadi pondasi dalam pengembangan sains dan teknologi. Oleh karena itu, masyarakat dengan segala keunikan kecerdasan individunya harus memiliki kemampuan literasi matematika yang memadai. Masyarakat dituntut mampu memanfaatkan matematika secara teoritis dan aplikatif (Fathani, 2016). mathematics is the key to opportunity, NCTM (Baiduri, 2015). Matematika adalah kunci kearah peluang-peluang. Bagi peserta didik keberhasilan mempelajarinya akan membuka pintu karier yang cemerang dimasa mendatang. Melihat pentingnya matematika dan peranannya dalam menghadapi kemajuan IPTEK dan persaingan global maka peningkatan mutu pendidikan matematika di semua jenis dan jenjang pendidikan harus selalu diupayakan.

Pada kenyataannya masih banyak siswa yang menanggapi bahwa matematika tidak lebih dari sekedar berhitung dan bermain dengan rumus-rumus dan angka-angka. Saat ini masih banyak siswa yang hanya menerima begitu saja pelajaran matematika disekolah, tanpa mempertanyakan mengapa dan untuk apa matematika harus diajarkan. Tidak jarang muncul keluhanan bahwa matematika merupakan momok yang menakutkan.

Salah satu tolak ukur atau patokan yang menentukan keberhasilan atau kegagalan dalam proses pembelajaran adalah hasil belajar. hasil ini diperoleh setelah melalui pengalaman belajar yang dapat diukur melalui tes. Menurut Muhibbin Syah secara garis besar faktor-faktor yang dapat mempengaruhi hasil belajar, yaitu : (1) faktor internal, yakni faktor dari dalam diri siswa berupa keadaan/ kondisi jasmani dan rohani siswa. (2) faktor ekternal (faktor dari luar), yakni kondisi sekitar siswa dan (3) faktor pendekatan belajar (approach to learning), yakni jenis upaya belajar siswa meliputi strategi dan metode yang digunakan siswa untuk melakukan kegiatan pembelajaran materi-materi pelajaran. Secara umum penyebab kesulitan belajar matematika siswa beragam dapat dibedakan menjadi, kesulitan yang disebabkan oleh faktor kognitif dan faktor non kognitif. Faktor kognitif mencakup kemampuan intelektual siswa dan cara siswa mencerna materi matematika didalam fikirannya. Sehubungan dengan cara siswa

mencema materi-materi matematika. Penyebab kesulitan belajar siswa tentang matematika salah satunya dapat bersumber pada kemampuan pemahaman konsep-konsep dasar matematika. Sedangkan non kognitif di antaranya pengajar, media pembelajaran, penilaian (evaluasi), sarana dan prasarana.

Menurut Sholeh dalam Ahmad (2011) memberi penjelasan bahwa dalam pelajaran matematika, siswa yang mengalami kesulitan belajar antara lain disebabkan oleh hal-hal sebagai berikut:

1. Siswa tidak dapat menangkap dengan benar. Siswa belum sampai ke proses abstraksi dan masih dalam dunia konkret. Dia belum sampai kepemahaman yang hanya tahu contoh-contoh, tapi tidak dapat mendeskipsikannya.

2. Siswa tidak mengerti arti lambang-lambang siswa hanya menuliskan atau mengucapkan tanpa dapat menggunakannya. Akibatnya, semua kalimat matematika menjadi tidak berarti baginya.

3. Siswa tidak dapat memahami asal-usul suatu prinsip. Siswa tau apa rumusnya dan menggunakannya, tetapi tidak mengetahui dimana atau dalam konteks apa prinsip itu digunakan.

4. Siswa tidak lancar menggunakan operasi dan prosedur. Ketidaksamaan menggunakan operasi dan prosedur terdahulu pengaruh kepada pemahaman prosedur laimya,

5. Kurangnya pengetahuan akan menghambat kemampuan siswa untuk memecahkan masalah matematika, sementara itu pelajaran terus berlanjut secara berjenjang.

Pada dasarnya setiap individu adalah unik. Setiap individu memiliki karakteristik khas, yang tidak dimiliki oleh individu lainnya (Mailili, 2016: 3). Perbedaan individu siswa dapat dilihat pada perbedaan tingkat kecakapan memecahkan masalah, taraf kecerdasasan, atau kemampuan berpikir kreatif. Selain itu siswa juga dapat berbeda dalam memperoleh, menyimpan serta menerapkan pengetahuan. Mereka dapat berbeda dalam cara pendekatan terhadap situasi belajar, dalam cara mereka menerima, mengorganisasi dan menghubungkan pengalaman-pengalaman belajar mereka, dalam hal cara mereka merespon terhadap metode pengajaran tertentu. Setiap orang memiliki cara-cara sendiri yang disukainya dalam menyusun apa yang dilihat, diingat dan dipikirkannya. Perbedaan-perbedaan antar pribadi yang menetap dalam menyusun dalam mengolah informasi serta pengalaman-pengalaman ini dikenal dengan gaya kognitif. Salah satu gaya kognitif yang telah dipelajari secara luas adalah gaya kognitif menurut pengertian witkin, yaitu (1) gaya kognitif tipe field Independent dan (2) gaya kognitf tipe field Dependent. Adanya perbedaan individu siswa ini maka diperlukan model pembelajaran yang efektif untuk membantu setiap siswa dalam menerima materi pelajaran serta sebagai alternatif dalam meyelesaikan masalah belajar matematika.

Sejalan dengan Permasalahan yang 
dikemukankan sebelumnya, kesulitan belajar matematika juga terjadi di Mts Alkhairaat Kalukubula, Berdasarkan hasil diskusi dengan salah satu guru matematika disekolah tersebut di peroleh informasi bahwa hasil belajar matematika siswa pada materi teorema phytagoras masih tergolong rendah, hal ini ditunjukkan dengan nilai ulangan harian siswa pada materi teorema phytagoras nilai rata-rata ketuntasan belajar klasikal diperoleh $45,25 \%$ yang berarti tingkat penguasaan materi siswa masih tergolong sangat rendah. Selain itu pemahaman konsep terhadap materi tersebut masih kurang hal ini terindentifikasi dari hasil pekerjaan siswa setelah diberikan tes observasi menunjukkan bahwa siswa kesulitan menyelesaikan soal dengan benar khususnya mencari nilai pada sisi segitiga yang berlaku dalam teorema phytagoras, siswa cenderung menghafal rumus yang diberikan dan tidak memahaminya sehingga ketika soal tidak biasa (berbeda dengan contoh) yang diberikan maka siswa akan kesulitan dalam menyelelesaikannya. Siswa akan menghadapi masalah jika kesalahan jawaban yang diperbuat dalam penyelesaian soal-soal teorema phytagoras tidak diperbaiki Artinya, jika kesulitan siswa tersebut tidak dicari jalan keluarnya maka ia menghadapi suatu masalah atau kegagalan dalam pembelajaran matematika. Salah satu upaya untuk pemecahan tentang hal tersebut adalah melakukan perbaikan proses pengajaran, dalam hal ini bagaimana guru menerapkan model, metode, strategi serta pendekatan pembelajaran yang sesuai dengan karakteristik siswa dalam hal ini meninjau gaya kognitif siswa yaitu gaya field independent dan field depedent.

Berdasarkan uraian diatas, Masalah ini sangat berkaitan dengan kemampuan belajar dan hasil belajar matematika berdasarkan gaya kognitif siswa yang dimilikinya. Untuk itu, perlu diteliti bagaimana gaya kognitif yang dimiliki siswa dan bagaimana gambaran hasil belajar matematika siswa. Oleh karena itu, tujuan penelitian ini adalah untuk mendeskripsikan Hasil Belajar Matematika Siswa Kelas VIII Mts Alkahiraat Kalukubula pada materi teorema phytagoras Ditinjau Dari Gaya Kognitif Field Independent dan Field Dependent.

\section{METODE PENELITIAN}

Penelitian ini dilaksanakan pada Mts Alkhairaat Kalukubula, yang berlokasi di jalan Guru Tua No. 167 Kalukubula kecamatan sigi biromaru kab. Sigi, Provinsi Sulawesi tengah. Jenis penelitian ini adalah penelitian deskriptif yang bersifat menggambarkan fakta hasil belajar matematika siswa kelas VIII dengan materi teorema phytagoras. pengambilan subjek dengan cara acak (Random Sampling) diambil dari masing-masing kelas dengan menggunakan daftar yang dikembangkan oleh peneliti. Langkah-langkah pengambilan subjek penelitian adalah:
Menetapkan kelas penelitian yaitu siswa kelas VIII yang telah mempelajari materi teorema phytagoras. Dipilihnya kelas VIII dengan pertimbangan:

a. Siswa kelas VIII telah mengikuti serangkaian materi teorema phytagoras yang telah diberikan guru di sekolah.

b. Karakter siswa kelas VIII relatif dikenal baik oleh guru dan tidak mengganggu kelas persiapan ujian Nasional.

c. Kegiatan siswa tidak terlalu padat sehingga memudahkan siswa untuk diteliti

d. Dari 104 siswa diambil secara acak sehingga siswa yang dijadikan subjek adalah 80 siswa untuk diambil sebagai sampel.

Instrumen yang digunakan untuk mengumpulkan data adalah :

1. Dengan tes soal yang terdiri dari soal uraian Matematika Kelas VIII sebanyak 10 butir soal uraian. Pada materi teorema phytagoras.

2. Angket tentang gaya kognitif.

Data yang terkumpul dari penelitian semuanya diolah atau dianalisis dengan menggunakan analisis statistik deskriptif Kriteria yang digunakan untuk menentukan pencapaian tingkat penguasaan pemahaman materi teorema phytagoras yaitu dengan menggunakan skala lima kategori yang disusun oleh Nurkancana dalam Latief (2013).

Tabel 1.Kategori Hasil belajar

\begin{tabular}{ccc}
\hline $\begin{array}{c}\text { Tingkat } \\
\text { Penguasaan \% }\end{array}$ & $\begin{array}{c}\text { Skor Hasil } \\
\text { Belajar }\end{array}$ & Kategori \\
\hline $0-54$ & $0-54$ & Sangat rendah \\
\hline $55-64$ & $55-64$ & Rendah \\
\hline $65-79$ & $65-79$ & Sedang \\
\hline $80-89$ & $80-89$ & Tinggi \\
\hline $90-100$ & $90-100$ & Sangat Tinggi \\
\hline
\end{tabular}

Identifikasi gaya kognitif subjek dalam penelitian ini dilakukan dengan berpedoman pada hasil tes gaya kognitif GEFT (Group Embeded Figures Test). yang terdiri dari 24 butir yang terbagi dalam 3 bagian, dimana 7 butir pada bagian I merupakan latihan dan 17 butir pada bagian II dan III merupakan inti dari GEFT. Setiap jawaban benar yang berarti subjek mampu menebalkan secara tepat bentuk gambar sederhana yang tersembunyi dalam gambar kompleks, diberi skor 1. Dalam penelitian ini, subjek yang mendapat skor $>12$ digolongkan FI dan subjek yang mendapat skor $\leq 12$ digolongkan FD.

Statistik deskriptif dimaksudkan untuk mendeskripsikan karakteristik responden berupa ratarata hasil belajar dan standar deviasi pada kelas eksperimen Untuk keperluan analisis digunakan distribusi frekuensi persentase rata-rata dan standar deviasi untuk masing-masing kelompok.

Adapun langkah-Iangkah dalam penyusunan data hasil pengamatan yang dikemukakan oleh Tiro adalah 
1. Rata-rata (Mean)

$$
\bar{x}=\frac{\Sigma x}{n} \text { atau } \bar{x}=\frac{\Sigma y}{n}
$$

Dimana:

$\bar{x}=$ nilai rata-rata $($ mean $)$

$\sum x=$ jumlah nilai hasil belajar matematika

sebelum bimbingan

$\Sigma y=$ jumlah nilai hasil belajar matematika

sesudah bimbingan

$\mathrm{n} \quad$ = banyaknya individu dalam sampel.

2. Presentase $(\%)$ nilai rata-rata

$$
P=\frac{f}{n} \times 100 \%
$$

Dimana:

$$
\begin{aligned}
& P=\text { Angka presentase } \\
& \mathrm{F}=\text { frekwensi yang dicari presentasenya } \\
& \mathrm{n}=\text { banyaknya sampel responden }
\end{aligned}
$$

3. Standar Deviasi

$$
\mathrm{SD}=\frac{\sqrt{\sum x^{2}}}{n} \text { atau } \mathrm{SD}=\frac{\sqrt{\sum y^{2}}}{n}
$$

$$
\begin{array}{ll}
\text { Dimana: } & \\
\text { SD } & =\text { Standar Deviasi } \\
\sum x^{2} & =\text { jumlah } x^{2} \text { sebelum bimbingan } \\
\Sigma y^{2} & =\text { jumlah } y^{2} \text { setelah bimbingan } \\
\mathrm{n} & =\text { banyaknya sampel responden }
\end{array}
$$

\section{HASIL DAN PEMBAHASAN}

Hasil penelitian yang diperoleh selama penelitian berlangsung dengan menggunakan SPSS yaitu hasil belajar siswa kelas VIII Mts. Alkhairaat Kalukubula dalam menyelesaikan soal teorema phytagoras berdasarkan gaya kognitif siswa yaitu: Field Independent dan Field Dependent berdasarkan data dari 80 siswa sebagai sampel penelitian diperoleh 40 siswa tergolong gaya kognitif Field Independent dan 40 siswa tergolong gaya kognitif Field Dependent.

\section{Desksripsi hasil belajar siswa Field} Independent pada materi teorema phytagoras

Hasil analisis statistik deskriptif siswa dengan gaya kognitif Field Independent dapat dilihat pada Tabel 2 berikut ini.
Tabel 2. Statistik Deskriptif Siswa Gaya Kognitif Field Independent

\begin{tabular}{cc}
\hline Statistik & Nilai Statistik \\
\hline Ukuran Sampel & 40,00 \\
\hline Rata-rata & 75,10 \\
\hline Nilai Tengah & 75,50 \\
\hline Standar Deviasi & 9,18 \\
\hline Variansi & 84,30 \\
\hline Rentang Skor & 35,00 \\
\hline Nilai terendah & 55,00 \\
\hline Nilai tertinggi & 90,00 \\
\hline
\end{tabular}

Berdasarkan Tabel 2 hasil belajar siswa kelas VIII Mts. Alkhairaat Kalukubuka dengan gaya kognitif Field Independent, dari 40 siswa yang tergolong dalam gaya kognitif Field Independent diperoleh dengan nilai rata-rata (Mean) 75,10 dari

\begin{tabular}{|c|c|c|c|c|}
\hline No. & Skor & Kategori & Frekuensi & $\begin{array}{c}\text { Presentasi } \\
(\%)\end{array}$ \\
\hline 1 & $0-54$ & Sangat rendah & 0 & 0 \\
\hline 2 & $55-64$ & Rendah & 5 & 12,5 \\
\hline 3 & $65-79$ & Sedang & 18 & 45 \\
\hline 4 & $80-89$ & Tinggi & 16 & 40 \\
\hline 5 & $90-100$ & Sangat Tinggi & 2 & 2,5 \\
\hline \multicolumn{3}{|c|}{ Jumlah } & 40 & 100 \\
\hline
\end{tabular}
skor ideal 100 . Nilai maksimum yang diperoleh siswa adalah 90 dan nilai minimum 55 dengan rentang (Range) 35. Simpangan baku (standar deviation) 9,18 dan variansi (variance) 84,30.

Adapun pengelompokan hasil belajar matematika siswa dengan gaya kognitif Field Independent dapat dilihat pada tabel 3 berikut :

Tabel 3. Distribusi frekuensi Siswa gaya kognitif Field Independent dalam menyelesaikan materi teorema phytagoras

Tabel 3 memberikan informasi yang lebih rinci dan jelas tentang skor kemampuan siswa Field Independent dalam menyelesaikan soal teorema phytagoras, dimana siswa memperoleh skor dalam kategori rendah ada 5 siswa $(12,5 \%)$, dalam kategori sedang sebanyak 18 siswa (45\%), siswa yang memperoleh skor dalam kategori tinggi ada 16 siswa (40\%) dan siswa yang memperoleh skor dalam kategori sangat tinggi ada 1 siswa (2,5\%). Rata-rata skor kemampuan siswa yang Field Independent dalam menyelesaikan soal teorema phytagoras adalah 75,10 apa bila dikonversi dalam skor pada Tabel 6, maka rata-rata tersebut berada dalam kategori sedang.

2. Deskripsi hasil belajar siswa Field Dependent pada materi teorema phytagoras.

Hasil analisis statistik deskriptif siswa dengan gaya kognitif Field Dependent dapat dilihat pada Tabel 4 berikut ini. 
Tabel 4. Statistik Deskriptif Siswa Gaya Kognitif Field Dependent

\begin{tabular}{cc}
\hline Statistik & Nilai Statistik \\
\hline Ukuran Sampel & 40,00 \\
\hline Rata-rata & 49,40 \\
\hline Nilai Tengah & 50,00 \\
\hline Standar Deviasi & 16,17 \\
\hline Variansi & 261,53 \\
\hline Rentang Skor & 55,00 \\
\hline Nilai terendah & 20,00 \\
\hline Nilai tertinggi & 75,00 \\
\hline
\end{tabular}

Berdasarkan Tabel 4 hasil belajar siswa kelas VIII Mts Alkhairaat Kalukubula dengan gaya kognitif Field Dependent diperoleh nilai rata-rata (Mean) 49,40 dari skor ideal 100. Nilai maksimum yang diperoleh siswa adalah 75 dan nilai minimum 20 dengan rentang (range) 55. Simpangan baku (Standar deviation) 16.17 dan Variansi (variance) 261,53.

Berdasarkan Tabel 4 hasil belajar siswa kelas VIII Mts Alkhairaat Kalukubula dengan gaya kognitif Field Dependent diperoleh nilai rata-rata (Mean) 49,40 dari skor ideal 100. Nilai maksimum yang diperoleh siswa adalah 75 dan nilai minimum 20 dengan rentang (range) 55 . Simpangan baku (Standar deviation) 16.17 dan Variansi (variance) 261,53.

Adapun pengelompokan hasil belajar matematika siswa dengan gaya kognitif Field Dependent dapat dilihat pada Tabel 5 berikut.

Tabel 5 Distribusi frekuensi siswa Field Dependent dalam menyelesaikan materi teorema phytagoras

\begin{tabular}{ccccc}
\hline No. & Skor & Kategori & Frekuensi & $\begin{array}{c}\text { Presentasi } \\
(\mathbf{\%})\end{array}$ \\
\hline 1 & $0-54$ & Sangat rendah & 22 & 55 \\
\hline 2 & $55-64$ & Rendah & 6 & 15 \\
\hline 3 & $65-79$ & Sedang & 12 & 30 \\
\hline 4 & $80-89$ & Tinggi & 0 & 0 \\
\hline 5 & $90-100$ & Sangat Tinggi & 0 & 0 \\
\hline \multicolumn{6}{c}{ Jumlah } & 40 & 100 \\
\hline
\end{tabular}

Tabel 5 memberikan informasi yang lebih rinci dan jelas tentang skor hasil belajar siswa Field Dependent dalam menyelesaikan soal teorema phytagoras. dimana siswa rnemperoleh skor dalam kategori sangat rendah ada 22 siswa $(55 \%)$, dalam kategori rendah ada 6 siswa (15\%), dalam kategori sedang ada 12 siswa (30\%). tidak ada siswa yang rnemperoleh skor dalam kategori tinggi dan sangat tinggi Rata-rata skor hasil belajar siswa yang Field Dependent dalam menyelesaikan soal teorema phytagoras adalah 49,40 apabila di dikonversi dalam skor pada Tabel 6, maka rata-rata tersebut berada dalam kategori sangat rendah. Perbandingan skor kemampuan siswa dalam menyelesaikan soal teorema phytagoras berdasarkan gaya kognitif Field Independent maupun Field Dependent dapat dilihat pada Tabel 6.

Pada Tabel 6 terlihat bahwa skor rata-rata kemampuan siswa dalam menyelesaikan materi teorema phytagoras untuk siswa dengan gaya kognitif Field Dependent berada pada kategori sangat rendah dengan rata-rata 49,40. Sedangkan siswa dengan gaya kognitif Field Independent berada pada kategori rendah dengan rata-rata 75,10. Dengan demikian dapat di simpulkan bahwa hasil belajar siswa Field Independent lebih tinggi dibandingkan dengan siswa Field Dependent dalam menyelesaiakan soal materi teorema phytagoras.

Hasil belajar siswa dalam menyelesaikan materi teorema phytagoras dengan gaya kognitif Field Dependent berada pada kategori sangat rendah dengan rata-rata 49,40. Sejalan dengan teori dari witkin bahwa siswa yang memiliki gaya kognitif Field Dependent tidak senang dengan pelajaran matematika, siswa Field Dependent lebih kuat mengingat informasi-informasi sosial seperti percakapan atau interaksi antar pribadi Dalam hal pelajaran, siswa tersebut lebih mudah mempelajari sejarah, bahasa dan ilmu pengetahuan sosial Siswa Field Dependent juga memerlukan petunjuk yang lebih banyak untuk memahami sesuatu, cenderung mempresepsi suatu pola sebagai suatu keseluruhan Sukar baginya untuk memusatkan perhatian pada satu aspek situasi atau menganalisis suatu pola menjadi bermacam-macam dan akan lebih baik jika diberikan petunjuk atau bimbingan secara ekstra dan berkelompok.

Sedangkan hasil belajar siswa dengan gaya kognitif Field Independent dalam menyelesaikan materi teorema phytagoras berada pada kategori rendah dengan rata-rata 75,10 . Juga sejalan dengan teori dari Witkin bahwa siswa dengan gaya kognitif Field Independent senang belajar matematika dan sains, cenderung mempresepsi bagian-bagian yang terpisah dari suatu pola menurut komponenkomponennya. Orang yang Field Independent dalam situasi sosial sebaliknya merasa ada tekanan dari luar (eksternal pressure), juga menanggapi situasi secara dingin, ada jarak, tidak sensitif dan dalam melaksanakan tugas atau menyelesaikan soal maka akan bekerja lebih baik jika diberikan kebebasan atau bekerja secara individu.

Tabel 6. Hasil Belajar siswa kelas VIII Mts Alkhairaat Kalukubula berdasarkan gaya Kognitif Field Independent maupun Field Dependent

\begin{tabular}{|c|c|c|c|c|}
\hline \multirow{2}{*}{ Gaya Kognitif } & \multicolumn{3}{|c|}{ Hasil Belajar Matematika } & \multirow[t]{2}{*}{ Kategori } \\
\hline & Maximum & Minimum & Rata- Rata & \\
\hline Field Independet & 75 & 25 & 49,40 & $\begin{array}{l}\text { Sangat } \\
\text { rendah }\end{array}$ \\
\hline Field Dependet & 90 & 55 & 75,10 & Sedang \\
\hline
\end{tabular}


Siswa memiliki cara tersendiri ditempuh menyusun apa yang dilihat, diingat dan dipikirkan. Mereka dapat berbeda dalam cara pendekatan terhadap situasi belajar, dalam cara mereka menerima, mengorganisasikan, dan menghubungkan pengalaman-pengalaman mereka, dalam cara mereka merespon terhadap metode pengajaran tertentu. Perbedaan-pcrbedaan itu bukan merupakan cerminan dari tingkat kecerdasan atau pola-pola kemampuan lain, akan letapi ada kaitannya denganmemproses dan menyusun informasi dan cara siswa mereaksi terhadap stimulus lingkungaa Perbedaan-perbedaan antara individu yang menetap dalam cara menyusun dan mengolah informasi serta pengalaman-pengalarnan ini dikenal sebagai gaya kognitif. gaya kognitif adalah gaya siswa mempersepsi dan menyusun informasi yang berasal dari lingkungan sekitar. Sesuai dengan hipotesis penelitian, diperoleh bahwa ada perbedaan hasil belajar siswa Field Dependent dan Field Independent dalam pembelajaran

Banyak variasi gaya kognitif yang diminati para peserta didik salah satunya adalah gaya kognitif Field Independent dan Field Dependent, implementasi dalam pembelajaran sangat menentukan pembelajaran. Suatu proses usaha yang dilakukan individu untuk memperoleh suatu perubahan tingkah laku yang baru secara keseluruhan sebagai hasil pengalaman individu itu sendiri dalam interaksi dengan lingkungannya.

Gaya kognitif tersebut mengandung kelebihan dan kekurangan. Kelebihan siswa gaya kognitif Field Dependent temyata lebih kuat mengingat informasi-informasi sosial seperti percakapan atau interaksi antar pribadi dalam hal pelajaran, siswa tersebut lebih mudah mempelajari sejarah, kesastraan, bahasa dan ilmu pengetahuan sosial Berbeda halnya dengan siswa yang memiliki gaya kognitif Field Independent, siswa ini lebih mudah mengurangi hal-hal yang kompleks dan lebih mudah memecahkan persoalan-persoalan sains, siswa Field Independent lebih mudah mempelajari ilmu pengetahuan alam dan matematika. Kemudian siswa yang Field Independent itu cenderung didominasi oleh perempuan dari pada Field Dependent. Sesuai dari sampel penelitian diteliti Proses penelitian sempat menghadapi kendali namum masih dapat diatasi, karena siswa yang diteliti itu tidak serius, bahkan penelitian tersebut dianggap tidak penting bagj mereka, tetapi kebanyakan siswa laki-laki yang terjadi seperti itu, sedangkan kelemahan dari peneliti, dimana peneliti belum mampu mengendalikan siswa tersebut, namun atas berkat bantuan seorang guru, sehingga penelitian tersebut berjalan dengan baik.

Penelitian ini menunjukkan bahwa ada perbedaan hasil belajar matematika siswa dengan gaya kognitif field indepent dan field dependent hasil ini sejalan dengan hasil penelitian Mailili
(2016), Putra (2014), Lutvianis (2014), Latief (2013), Yasa, dkk (2013), Al-salameh (2011), dan Nuraeni (2011).

\section{SIMPULAN}

Berdasarkan hasil penelitian maka dapat diinterpretasikan bahwa hasil belajar matematika pada materi teorema phytagoras siswa yang bergaya kogntif field independent berada pada kategori sedang dan siswa bergaya kognitif field dependent berada pada kategori sangat rendah sehingga dapat disimpulkan bahwa terdapat perbedaan hasil belajar matematika siswa, hal ini berarti gaya kognitif berkonstribusi dalam hasil belajar matematikanya. Oleh karenanya dalam pembelajaran matematika perbedaan individu siswa menjadi perhatian terutama dalam pemilihan metode, media atau evaluasi.

\section{UCAPAN TERIMAKASIH}

Penulis mengucapkan terimakasih kepada segenap tim Pengelola Jurnal Anargya yang telah memberikan kesempatan kepada penulis untuk mempublikasikan karya ilmiahnya

\section{DAFTAR PUSTAKA}

Al-Salameh, E.M. 2011. A Study of Al-Balqa' Applied University Students Pusat Kurikulum, Balitbangdiknas, Jakarta.

Baiduri. 2015. Gaya Kognitif Dan Hasil Belajar Matematika Siswa Field DependenceIndependence. Jurnal Aksioma, 6(1):64-72.

Fathani, Abdul Halim. 2016. Journal Edu Sains: Jurnal Pendidikan Sains \& Matematika 4(2) $: 1-12$

Fathani, Abdul Halim . 2012. Matematika Hakikat dan Logika. Yogyakarta: Ar-Ruzz Media

Latief, Nila S. 2013. Pengaruh Metode Mengajar dan Gaya Kognitif Terhadap Hasil Belajar Matematika Siswa Kelas VIII MTsS Kabupaten Maros.(Tesis). Makassar: PPs. Universitas Negeri Makassar.

Lutvianis, Vina (2014). Perbedaan Hasil Belajar Berdasarkan Gaya Kognitif Siswa Pada Pelajaran Matematika Kelas VIII Di UPTD SMP Negeri2 Sumbergempol Tulungangung. (Skripsi). $\quad$ http://digilib.iaintulungagung.ac.id. Diakses 2 Agustus 2016.

Mailili, Wahyuni H. (2016). Pengaruh model pembelajaran terhadap hasil belajar matematika ditinjau dari gaya kognitif siswa.Integral Jurnal Matematika dan Pembelajarannya 2(1) : 1-22.

Nuraeni. 2011. Deskripsi Kemampuan Pemecahan Masalah SPLDV Berdasarkan Gaya Kognitif Siswa MTs Muallimin Makassar. (Tesis). Makassar: PPs UNM

Putra, Aji Permana. 2014. Eksperimentasi Pendekatan Pembelajaran Matematika 
Realistik (PMR) dan Pendekatan Pembelajaran Open-Ended pada Materi Segitiga dan Segiempat Ditinjau dari Gaya Kognitif Siswa Kelas VII SMP Negeri seKabupaten Pacitan. Numeracy, 1(2) :1-10.

Sugiyono. 2011. Metode Penelitian Kuantitatif, Kualitatif, dan $R \& D$. Bandung: Alfabeta.

Sugiono. 2009. Statistika untuk Penelitian. Bandung: Alfabetha

Tiro, M. A. 2010. Penelitian: Skripsi, Tesis, dan Disertasi. Makassar: Andira Publisher.

Tiro, M. A. \& Arbianingsih. 2011. Teknik Pengambilan Sampel. Makassar: Andira Publisher.

Tiro, M. A. \& Sukarna. 2012. Pengembangan Instrumen Pengumpulan Data Penelitian. Makassar: Andira Publisher

Trihendradi, C. 2012. Step by Step SPSS 20 Analisis Data Statistik. Yogyakarta: C. V. Andi Offset.

Yasa, Adi,made,I, Sadra,I,Wayan,Suweken Gede. 2013. Pengaruh Pendidikan Matematika Realistik dan Gaya Kognitif Terhadap Prestasi Hasil Belajar Matematika Siswa, ejurnal PPs. Universitas Ganesha Program Studi matematika ,2.pasca.undiksha.ac.id/ejournal/index.php/JPM/.../664. Diakses tanggal 2 Agustus 2016. 